\title{
Differential Gene Expression in Coiled versus Flow-Diverter-Treated Aneurysms: RNA Sequencing Analysis in a Rabbit Aneurysm Model
}

(D) A. Rouchaud, (D). Johnson, (DE. Thielen, DD. Schroeder, (D).-H. Ding, (DD. Dai, (D)W. Brinjikji, (D). Cebral, DD.F. Kallmes, and D. Kadirvel $0=$

\begin{abstract}
BACKGROUND AND PURPOSE: The biologic mechanisms leading to aneurysm healing or rare complications such as delayed aneurysm ruptures after flow-diverter placement remain poorly understood. We used RNA sequencing following implantation of coils or flow diverters in elastase aneurysms in rabbits to identify genes and pathways of potential interest.
\end{abstract}

MATERIALS AND METHODS: Aneurysms were treated with coils $(n=5)$ or flow diverters $(n=4)$ or were left untreated for controls $(n=6)$. Messenger RNA was isolated from the aneurysms at 4 weeks following treatment. RNA samples were processed by using RNA-sequencing technology and were analyzed by using the Ingenuity Pathway Analysis tool.

RESULTS: With RNA sequencing for coiled versus untreated aneurysms, 464/9990 genes (4.6\%) were differentially expressed (58 downregulated, 406 up-regulated). When we compared flow-diverter versus untreated aneurysms, 177/10,041 (1.8\%) genes were differentially expressed (8 down-regulated, 169 up-regulated). When we compared flow-diverter versus coiled aneurysms, 13/9982 (0.13\%) genes were differentially expressed ( 8 down-regulated, 5 up-regulated). Keratin 8 was overexpressed in flow diverters versus coils. This molecule may potentially play a critical role in delayed ruptures due to plasmin production. We identified overregulation of apelin in flow diverters, supporting the preponderance of endothelialization, whereas we found overexpression of molecules implicated in wound healing (dectin 1 and hedgehog interacting protein) for coiled aneurysms. Furthermore, we identified metallopeptidases 1, 12, and 13 as overexpressed in coiled versus untreated aneurysms.

CONCLUSIONS: We observed different physiopathologic responses after endovascular treatment with various devices. Flow diverters promote endothelialization but express molecules that could potentially explain the rare delayed ruptures. Coils promote wound healing and express genes potentially implicated in the recurrence of coiled aneurysms.

ABBREVIATIONS: DAPL1 = death associated protein-like 1; FGFBPI = fibroblast growth factor binding protein $1 ;$ HHIP = hedgehog-interacting protein; IA = intracranial aneurysm; IL6 = interleukin 6; IPA = Ingenuity Pathway Analysis; MMP = matrix metalloproteinase; mRNA = messenger RNA; PRND = prion protein 2; RNA-seq $=$ RNA sequencing; SRCINI = SRC kinase signaling inhibitor 1

E ndovascular treatment is now considered the standard of care for most intracranial aneurysms (IAs). Numerous endovascular tools exist for the treatment of IAs, and flow-diverting devices

Received September 16, 2015; accepted after revision November 10 From the Applied Neuroradiology Laboratory (A.R., C.J., E.T., D.S., Y.-H.D., D.D., W.B., D.F.K., R.K.) and Department of Radiology (W.B., D.F.K.), Mayo Clinic, Rochester, Minnesota; and Department of Bioengineering (J.C.), George Mason University, Fairfax, Virginia.

This work was supported by research grant NS076491 from the National Institutes of Health. Aymeric Rouchaud was supported by a research grants from the French Society of Radiology and the Therese Planiol Foundation.

Please address correspondence to Aymeric Rouchaud, MD, Neuroradiology Research Laboratory, Mayo Clinic, 200 First St SW, Rochester, MN 55905; e-mail: Rouchaud.Aymeric@mayo.edu, aymeric.rouchaud@gmail.com

-- Indicates open access to non-subscribers at www.ajnr.org

三 Indicates article with supplemental on-line tables.

http://dx.doi.org/10.3174/ajnr.A4648 have elicited much interest, with good occlusion rates. ${ }^{1}$ However, the biologic mechanisms driving IA physiopathology remain poorly understood, including the mechanisms for formation, rupture, growth, healing, or device-related complications, and need further elucidation. Indeed, endovascular devices used for the treatment of IAs are not simply inert mechanical devices used to seal the aneurysm neck without any interaction with the host; rather, they interact with different biologic processes with the aim of definitely healing the aneurysm. Those biologic interactions may vary according to the device used or depending on the local biologic conditions and sometimes lead to nonocclusion of the aneurysm or to very rare but devastating complications such as delayed rupture. ${ }^{2-4}$ It is important to understand the biologic processes after endovascular treatment to optimize the devices used for the treatment of IAs and try to prevent potential complications. 
Previous studies explored the mechanisms of aneurysm healing following endovascular treatments, but they have mostly focused at the tissue, cellular, or molecular levels. ${ }^{5-7}$ Endovascular coiling primarily elicits thrombus formation in the aneurysm cavity and then promotes neointima formation across the neck to seal the aneurysm cavity from the circulation, ${ }^{5,8}$ but long-term occlusion rates are poor, with high rates of recanalization due to lack of aneurysm healing. ${ }^{9,10}$ On the contrary, occlusions rates following flow diversion are high and likely driven by endothelialization of the device from endothelial cells originating from the parent artery. ${ }^{6,11}$ However, despite high rates of occlusion and good clinical outcomes, ${ }^{5}$ flow-diverter devices have been associated with the occurrence of previously unobserved complications. Indeed, several cases of delayed aneurysm rupture have been reported with fatal outcomes. $^{3,4}$

Even if this complication is very rare and occurs in $<1 \%$ of cases, controversy exists surrounding the mechanism, and it appears important to try to explain it. Several mechanisms have been proposed to explain this complication, such as flow modifications $^{2}$ or a deleterious impact of the intra-aneurysm thrombus trapped by the flow diverter. ${ }^{3}$ Gene-regulation studies have previously investigated the impact of selected key molecules such as metallopeptidases, fibronectin, and collagen, potentially involved in the healing of aneurysms following coil or flow-diverter embolization. ${ }^{12-14}$ However, these prior studies did not provide a global overview of the biologic pathways involved in those different treatment options. ${ }^{15}$ Recently, microarray and RNA sequencing (RNA-seq) have been used to compare messenger RNA (mRNA) and microRNA expression in both humans and animal models to better understand the molecular mechanisms of aneurysm healing. ${ }^{16,17}$ However, none of these previous studies have compared coiled or flowdiverter-treated aneurysms. ${ }^{18}$ We used RNA-seq technology following implantation of coils or flow diverters in elastaseinduced saccular aneurysms in rabbits to identify genes and pathways of potential clinical interest and to determine whether differential pathways exist for the healing of coiled and flow-diverter-treated aneurysms.

\section{MATERIALS AND METHODS}

\section{Aneurysm Creation, Treatment, and Follow-Up}

The Mayo Clinic Animal Care and Use Committee approved all procedures before initiation of the study. Some of the rabbits used in this study were originally used as part of another investigation, in which we compared the gene expression between untreated aneurysms with contralateral carotid arteries ${ }^{16}$ and prior analyses of the expression of selected vascular remodeling molecules following coil and flow-diverter treatment. ${ }^{15}$ Elastase-induced saccular aneurysms were created in 16 New Zealand white rabbits (body weight, 3-4 kg). Detailed procedures for aneurysm creation have been previously described in depth. ${ }^{19}$ Aneurysms were permitted to mature for at least 3 weeks after creation. Then they were either embolized with platinum coils $(n=5)$ or treated with flow diverters (Pipeline Embolization Device; Covidien, Irvine, California) as previously described ${ }^{20}(n=4)$ or left untreated $(n=6)$. At 4 weeks following treatment, follow-up DSA of the aortic arch was performed. The animals were then euthanized by using a lethal injection of pentobarbital. Animals with untreated aneurysms were euthanized at 12 weeks following aneurysm creation. The aneurysm samples were harvested, and the samples were immediately snap frozen in liquid nitrogen and kept frozen at $-70^{\circ} \mathrm{C}$ until use.

\section{RNA Extraction}

RNA was isolated from frozen tissues by using the miRNeasy Mini Kit (Qiagen, Valencia, California). The quantity of the RNA was measured by using spectrophotometry, and the integrity of the RNA was confirmed by electrophoretic separation by using the 2100 Bioanalyzer (Agilent Technologies, Santa Clara, California).

\section{RNA Sequencing}

RNA libraries were prepared according to the manufacturer's instructions for the TruSeq RNA Sample Prep Kit v2 (Illumina, San Diego, California). Then the libraries were loaded onto paired end-flow cells following the standard protocol of Illumina by using the cBot and cBot Paired-End Cluster Kit, Version 3, and HCS, Version 2.0.12 data collection software (Illunina). Base calling was performed by using RTA, Version 1.17.21.3 (Illumina).

\section{Bioinformatics Analysis}

The processing of the mRNA and microRNA data was performed by using MAP-RSeq (Version 1.2.1.3). ${ }^{21}$ MAP-RSeq consists of the following steps: alignment, quality control, obtaining genomic features per sample, and finally summarizing the data across samples. The pipeline provides detailed quality control data to estimate the distance between paired-end reads, evaluates the sequencing depth for alternate splicing analysis, determines the rate of duplicate reads, and calculates the read depth across genes by using the RSeQC (Version 2.3.2 $)^{22}$ software. Paired-end reads are aligned by Tophat (Version 2.0.6; https://ccb.jhu.edu/software/tophat/index.shtml ${ }^{23}$ against the April 2009 OryCun2 genome build by using the Bowtiel.aligner $^{24}$ option (http://www.broadinstitute.org/cancer/ software/genepattern/modules/docs/Bowtie.aligner/4). Gene counts were generated by using HTSeq (Version 0.5.3p9) ${ }^{25}$ software, and the gene annotation files were obtained from Ensembl (ftp://ftp. ensembl.org/pub/release75/gtf/oryctolagus_cuniculus/Oryctolagus_ cuniculus.OryCun2.0.75.gtf.gz) and the University of California, Santa Cruz (http://hgdownload.soe.ucsc.edu/downloads.html\#rabbit). Differential expression comparing the normal tissue versus aneurysm in the same rabbit was computed by using the edgeR algorithm (Version 2.6.2) across all samples. Human orthologs were assigned by using ExoLocator (http://exolocator.bii.a-star.edu.sg/). ${ }^{26}$ The pathway analysis leveraged the Ingenuity Pathway Analysis (IPA; http://www.winsite.com/ingenuity/ingenuity+ pathway+ analysis/ $/{ }^{27}$ software to identify pathways enriched with human ortholog targets. IPA identified the involvement of different pathways according to the number of genes of the specific pathway that were differentially expressed in the compared groups. A pathway is considered more involved than another one if more genes of this specific pathway are found up- or down-regulated according to the prespecified values.

AJNR Am J Neuroradiol 37:1114-21 Jun 2016 www.ajnr.org 1115 
Table 1: Top up- and down-regulated molecules comparing coiled versus untreated aneurysms, determined by IPA ${ }^{\mathrm{a}}$

\begin{tabular}{|c|c|c|c|c|c|}
\hline \multicolumn{3}{|c|}{ Top Up-Regulated Molecules } & \multicolumn{3}{|c|}{ Top Down-Regulated Molecules } \\
\hline Gene Name & Description & Exp. Value & Gene Name & Description & Exp. Value \\
\hline MMP1 & $\begin{array}{l}\text { Matrix metallopeptidase } 1 \text { (interstitial } \\
\text { collagenase) }\end{array}$ & 8.407 & SRCINI & SRC kinase signaling inhibitor 1 & -4.210 \\
\hline MAР3К19 & $\begin{array}{l}\text { Mitogen-activated protein kinase } \\
\text { kinase kinase } 19\end{array}$ & 7.854 & DAPL1 & Death associated protein-like 1 & -3.922 \\
\hline TREML2 & $\begin{array}{l}\text { Triggering receptor expressed on } \\
\text { myeloid cells-like } 2\end{array}$ & 7.583 & HHIP & Hedgehog interacting protein & -3.512 \\
\hline FGF23 & Fibroblast growth factor 23 & 7.423 & $M P Z$ & Myelin protein zero & -3.400 \\
\hline MMPI3 & $\begin{array}{l}\text { Matrix metallopeptidase } 13 \\
\quad \text { (collagenase 3) }\end{array}$ & 7.201 & MYH7B & $\begin{array}{l}\text { Myosin, heavy chain 7B, cardiac } \\
\text { muscle, } \beta\end{array}$ & -3.342 \\
\hline SLAMF7 & SLAM family member 7 & 6.670 & PCDHAC2 & Protocadherin $\alpha$ subfamily C, 2 & -3.112 \\
\hline CXCL13 & Chemokine ( $\mathrm{C}-\mathrm{X}-\mathrm{C}$ motif) ligand 13 & 6.490 & THRSP & Thyroid hormone responsive & -3.089 \\
\hline$X D H$ & Xanthine dehydrogenase & 6.298 & CYP2D6 & $\begin{array}{l}\text { Cytochrome P450, family 2, } \\
\text { subfamily D, polypeptide } 6\end{array}$ & -2.991 \\
\hline IBSP & Integrin-binding sialoprotein & 6.221 & USH2A & $\begin{array}{l}\text { Usher syndrome } 2 A \text { (autosomal } \\
\text { recessive, mild) }\end{array}$ & -2.932 \\
\hline MMPI2 & $\begin{array}{l}\text { Matrix metallopeptidase } 12 \text { (macrophage } \\
\text { elastase) }\end{array}$ & 6.206 & SORCSI & $\begin{array}{l}\text { Sortilin-related VPS10 domain } \\
\text { containing receptor } 1\end{array}$ & -2.703 \\
\hline
\end{tabular}

Note:-Exp. indicates expression.

${ }^{a}$ Values are expressed as log-fold change.

\section{Quantitative Real-Time Polymerase Chain Reaction Analysis}

The mRNA expression of selected genes was assessed by quantitative real-time polymerase chain reaction. These selected genes were prion protein 2 ( $P R N D)$, fibroblast growth factor-23, matrix metalloproteinase $(M M P)$, SRC kinase signaling inhibitor 1 (SRCIN1), death associated protein-like 1 (DAPL1), and hedgehog-interacting protein (HHIP). Briefly, first, strand complementary DNAs were synthesized from $500 \mathrm{ng}$ of total RNA by using a synthesis system (SuperScript III First-Strand Synthesis System; Invitrogen, Grand Island, New York). Then, real-time polymerase chain reaction was performed with a cycler (iCycler; Bio-Rad, Hercules, California) by using the SYBR Green PCR kit (Quantigen, Hilden, Germany). The specific primers were designed from corresponding sequences obtained from the GenBank by using a Web tool (Primer 3; http://frodo.wi.mit.edu/primer3/).

\section{Statistical Analysis}

The $t$ test statistics and corresponding $P$ values were used as a measure of the mean change in expression between the test and control groups relative to the variability. The primary assessment compared each treatment group versus the control group. We additionally had a secondary assessment comparing treatment groups against each other. The EdgeR tool was used to test for a normal distribution of the data. The $t$ test-based $P$ values were adjusted for multiple comparisons by using the false discovery rate multiple-correction approach. ${ }^{28}$ Genes were considered differentially expressed in case of a fold change of 2 (a log-value of $>2$ was considered up-regulated, whereas a log-value of $\leq 2$ was considered down-regulated), with a false discovery rate $\leq 0.1$ and a $P$ value $<.05$.

\section{RESULTS}

\section{Coiled versus Untreated Aneurysms}

All aneurysm treatments with coils were successful without any recurrence at follow-up. Using the criteria above for differential expression, we identified 464 of 9990 (4.6\%) genes as being dif- ferentially expressed compared with untreated aneurysms. Of these 464 genes, 58 were down-regulated and 406 were up-regulated (On-line Table 1). The most up- and down-regulated molecules are presented in Table 1. Of the 10 most up-regulated, 3 are metalloproteinases: MMP1 (8.4-fold), MMP12 (6.1-fold), and MMP13 (7.2-fold) involved in the breakdown of extracellular matrix and interstitial collagen for tissue remodeling. The most down-regulated protein is HHIP, decreased 3.5-fold compared with untreated aneurysms. The most involved pathways are shown in On-line Table 2. Those pathways are generally related to inflammatory responses, including $\mathrm{T}$ - and B-cell and interleukin-10 involvement and cell-to-cell signaling as well as granulocyte and agranulocyte adhesion and diapedesis. Those pathways involve up-regulation of $M M P$ s such as $M M P 1, M M P 3, M M P 12$, $M M P 13$, and interleukins.

\section{Flow-Diverter-Treated versus Untreated Aneurysms}

All aneurysm treatments with flow diverters were successful without any delayed rupture at follow-up. Using the criteria above for differential expression, we identified 177 of 10,041 (1.8\%) genes as being differentially expressed. Of these 177 genes, 8 were downregulated and 169 were up-regulated (On-line Table 3). The most up- and down-regulated molecules are presented in Table 2. Of the 10 most up-regulated, fibroblast growth factor 23 increased 5.7-fold, keratin 8 increased 6.2-fold, MMP1 increased 4.5-fold, apelin increased 4.4-fold, and interleukin 6 (IL6) increased 4.4fold compared with untreated aneurysms. Of the most downregulated molecules, DAPL1 decreased by 3.8-fold, SRCIN1 decreased by 3.3 -fold, macrophage receptor with collagenous structure decreased by 2.4 -fold, and fibroblast growth factor binding protein 1 (FGFBP1) decreased by 2.2 -fold. The most involved pathways are shown in On-line Table 4. The most involved pathway was the atherosclerosis signaling pathway with 9 up-regulated genes compared with nontreated aneurysms. Similar to coiled aneurysms, agranulocyte adhesion and diapedesis pathways and the cell-to-cell signaling pathway were involved with flow diverters. 
Table 2: Top up- and down-regulated molecules comparing flow-diverted versus untreated aneurysms, determined by IPA ${ }^{\text {a }}$

\begin{tabular}{|c|c|c|c|c|c|}
\hline \multicolumn{3}{|c|}{ Top Up-Regulated Molecules } & \multicolumn{3}{|c|}{ Top Down-Regulated Molecules } \\
\hline Gene Name & Description & Exp. Value & Gene Name & Description & Exp. Value \\
\hline$P R N D$ & Prion protein 2 (dublet) & 8.719 & DAPL1 & Death associated protein-like 1 & -3.752 \\
\hline KRT8 & Keratin 8 & 6.233 & SRCIN1 & $S R C$ kinase signaling inhibitor 1 & -3.295 \\
\hline FGF23 & Fibroblast growth factor 23 & 5.662 & FAM150A & $\begin{array}{l}\text { Family with sequence similarity } 150 \text {, } \\
\text { member A }\end{array}$ & -2.555 \\
\hline SIRPBI & Signal-regulatory protein $\beta 1$ & 5.463 & MARCO & $\begin{array}{l}\text { Macrophage receptor with collagenous } \\
\text { structure }\end{array}$ & -2.396 \\
\hline CXCL8 & Chemokine (C-X-C motif) ligand 8 & 4.781 & $L E C T 7$ & Leukocyte cell derived chemotaxin 1 & -2.373 \\
\hline GPR158 & G protein-coupled receptor 158 & 4.747 & SCIN & Scinderin & -2.287 \\
\hline MMPI & $\begin{array}{l}\text { Matrix metallopeptidase } 1 \text { (interstitial } \\
\text { collagenase) }\end{array}$ & 4.467 & FGFBPI & $\begin{array}{l}\text { Fibroblast growth factor binding } \\
\text { protein } 1\end{array}$ & -2.183 \\
\hline HMGA2 & High mobility group AT-hook 2 & 4.412 & MYH7B & Myosin, heavy chain 7B, cardiac & -2.107 \\
\hline APLN & Apelin & 4.412 & & muscle, $\beta$ & \\
\hline IL6 & Interleukin 6 (interferon, $\beta$ 2) & 4.375 & & & \\
\hline
\end{tabular}

Note:-Exp. indicates expression.

a Values are expressed as log-fold change.

Table 3: Top up- and down-regulated molecules comparing flow-diverted versus coiled aneurysms, determined by IPA ${ }^{\mathrm{a}}$

\begin{tabular}{|c|c|c|c|c|c|}
\hline \multicolumn{3}{|c|}{ Top Up-Regulated Molecules } & \multicolumn{3}{|c|}{ Top Down-Regulated Molecules } \\
\hline Gene Name & Description & Exp. Value & Gene Name & Description & Exp. Value \\
\hline KRT8 & Keratin 8 & 4.266 & PDILT & $\begin{array}{l}\text { Protein disulfide isomerase-like, testis } \\
\text { expressed }\end{array}$ & -4.172 \\
\hline BSG & Basigin/EMMPRIN & 3.799 & LIPA & $\begin{array}{l}\text { Lipase A, lysosomal acid, cholesterol } \\
\text { esterase }\end{array}$ & -3.820 \\
\hline TLDC2 & $\begin{array}{l}\text { TBC/LysM-associated domain } \\
\text { containing } 2\end{array}$ & 3.363 & EXPH5 & Exophilin 5 & -2.872 \\
\hline$P R P H$ & Peripherin & 2.895 & ZNF483 & Zinc finger protein 483 & -2.667 \\
\hline \multirow[t]{4}{*}{$R M R P$} & RNA component of mitochondrial & 2.671 & KLHL14 & Kelch-like family member 14 & -2.470 \\
\hline & RNA processing endoribonuclease & & CLEC7A & C-type lectin domain family 7 member $A$ & -2.451 \\
\hline & & & TCN1 & $\begin{array}{l}\text { Transcobalamin I (vitamin B12 binding } \\
\text { protein, R binder family) }\end{array}$ & -2.432 \\
\hline & & & COL25A1 & Collagen, type XXV, $\alpha$ & -2.285 \\
\hline
\end{tabular}

Note:-Exp. indicates expression.

a Values are expressed as log-fold change.

\section{Flow-Diverter-Treated versus Coiled Aneurysms}

Using the criteria above for differential expression, we identified 13 of $9982(0.13 \%)$ genes as being differentially expressed. Of these 13 genes, 8 were down-regulated and 5 were up-regulated (Table 3). Of the 13 differentially expressed molecules when comparing flow-diverter-treated IAs with coiled aneurysms, keratin 8 increased 4.3-fold, and basigin increased 3.8-fold. Protein disulfide isomerase-like was overexpressed in the coiled group compared with the flow-diverter group at 4.2-fold; and C-type lectin domain family 7 , member A (also called dectin 1 ) was over-expressed 2.5-fold in the coiled group. Due to the low number of differentially expressed molecules when comparing coiled with flow-diverter-treated aneurysms, it was not possible to identify specific pathways differentially involved.

\section{Validation of Microarray Data}

Verification of differential gene expression in the aneurysm and control artery was performed in 5 selected genes from the top upor down-regulated genes identified by RNA-seq. Those selected genes were $P R N D$, fibroblast growth factor 23, MMP1, SRCIN1, DAPL1, and HHIP. Results obtained by reverse transcription polymerase chain reaction for gene expression levels varied in the same way and in comparable amplitude as those obtained with RNA-seq. Results of reverse transcription polymerase chain reaction are presented in On-line Table 5.

\section{DISCUSSION}

This study found differential expression in a large assortment of genes in tissue from coiled or flow-diverter-treated aneurysms compared with untreated aneurysms. The differentially expressed genes are mostly related to the inflammatory response and cellular migration. These findings may provide insight into the biologic effects of coils and flow diverters and highlight pathways to better understand and optimize the outcomes after endovascular treatment of intracranial aneurysms.

Our results showed that relatively few genes were differentially expressed when comparing coiled versus flow-diverter-treated aneurysms. These findings show that despite 2 different approaches, the response to the device used for the endovascular treatment of IAs did not vary substantially. These findings further demonstrate that the observed gene modifications were mostly driven by the aneurysm itself rather than by the device and imply that the mechanisms leading to aneurysm occlusion are somewhat similar, regardless of the device used. However, some genes were differentially expressed in the flow-diverter-treated group compared with the coiled group.

Specifically, the most up-regulated molecule was keratin 8, which acts as a binding site for plasminogen. ${ }^{29}$ This overexpression of plasminogen receptors could be deleterious to the treated aneurysms. Indeed, the association of plasminogen with cellular 
receptors facilitates its activation in plasmin. ${ }^{30,31}$ Then, plasmin generated from plasminogen is able to degrade extracellular matrix components directly or indirectly by activating ( $M M P-1,3$, and 9). ${ }^{32,33}$

Our study also found that apelin is up-regulated in flow-diverter-treated aneurysms compared with coiled aneurysms. This molecule significantly reduces aneurysm formation in the elastase model of abdominal aortic aneurysms by decreasing macrophage burden likely due to an apelin-mediated decrease in proinflammatory cytokine and chemokine activation. ${ }^{34,35}$ It has also been demonstrated that apelin is present to a limited degree in endothelial cells, with a potent ability to stimulate the proliferation of cultured human umbilical vein endothelial cells. ${ }^{36}$ In our study, apelin was overexpressed in flow-diverter-treated aneurysms compared with coiled aneurysms; this overexpression is potentially a key factor for the promotion of endothelial cells, leading to stent endothelialization and aneurysm occlusion. ${ }^{37}$

These current results also confirm the role of inflammation after the implantation of devices for the treatment of IAs. Metalloproteinases are known to be involved in thrombus homeostasis in IAs, but mainly MMP2 and MMP9 have been described in this pathology. ${ }^{38-41}$ Here, we report the important role of other $M M P$ molecules (MMP1, -12, and -13) overexpressed in coiled versus untreated IAs. These MMPs have been reported as being implicated in abdominal aortic aneurysm formation and progression. ${ }^{42-52}$ However their impact has not been extensively described in the setting of IAs. ${ }^{50}$ We suspect that this increased level of MMPs in coiled aneurysms is linked to recanalization because MMP-9 levels are associated with aneurysm recanalization and recurrence. ${ }^{53}$ The RNA-seq also found that basigin (also known as extracellular matrix metalloproteinase inducer) is up-regulated in flow-diverter-treated aneurysms compared with coiled aneurysms. This molecule is known to regulate different MMPs, especially MMP2 and MMP9. ${ }^{54,55}$ The increased level of basigin in flow diverters could explain the higher level of those MMPs in flow-diverter-treated aneurysms as previously described. ${ }^{15}$

Furthermore, the macrophage receptor with collagenous structure is another differentially expressed gene in our study. This molecule is associated with thrombus-free aneurysms in a study comparing thrombus-free and thrombus-covered walls of abdominal aortic aneurysms. ${ }^{56}$ In our study, we observed a downregulation of macrophage receptor with collagenous structure in the flow-diverter group, suggesting an increased implication of intra-aneurysmal thrombosis compared with untreated aneurysms and the potential role of intra-aneurysmal thrombus for delayed aneurysm rupture associated with flow diverters. ${ }^{3,57}$

Regarding the potential deleterious role of keratin 8 in flow diverters, the generation of plasmin induces neutrophil aggregation, monocyte chemotaxis, and expression of proinflammatory molecules ${ }^{58}$ via multiple signaling pathways, including nuclear factor- $\kappa \mathrm{B} .{ }^{59}$ This involvement of the fibrinolytic system has been previously highlighted in abdominal aortic aneurysm pathology. ${ }^{60}$ In abdominal aortic aneurysms, plasminogen is present in the mural thrombus. ${ }^{61}$ This mural thrombus, by trapping polymorphonuclear leukocytes and adsorbing plasma components, could act as a source of proteases in aneurysms, which may play a critical role in enlargement and rupture. ${ }^{57}$ Furthermore, abdominal aortic aneurysm diameter is correlated with the level of plasmin activity in the abdominal aortic aneurysm wall. ${ }^{61}$ The overexpression of keratin 8 in flow-diverter-treated IAs could explain the deleterious issue in the rare cases of delayed aneurysm rupture after flow diverters. This overexpression of keratin 8 associated with a large amount of intrasaccular thrombus after flow-diverter placement supports intra-aneurysmal thrombosis as a possible cause of delayed aneurysm rupture after flow-diversion treatment ${ }^{3}$; however, the confirmation of this hypothesis would need further dedicated experiments to precisely determine the impact of keratin 8 .

Another important function for aneurysm occlusion after endovascular treatment is wound healing, consisting subsequently of thrombus formation, myofibroblast invasion, and extracellular matrix deposition. ${ }^{5,12,62}$ C-type lectin domain family 7, member A (dectin 1) is a molecule promoting wound healing by the enhanced production of collagen matrices with $\beta$-glucans. ${ }^{63-65}$ Our results show that dectin 1 is approximately 4 times overexpressed in coiled IAs compared with flow-diverter-treated IAs. This finding suggests that wound healing is a process that is much more preponderant in coils than in flow-diverter treatment. FGFBP1 is another molecule promoting wound healing. ${ }^{66,67}$ The present results show that FGFBP1 is decreased in flow-diverter-treated aneurysms compared with untreated aneurysms; this decrease supports the idea that aneurysm occlusion after flow-diverter therapy is not related to wound-healing mechanisms but mostly to endothelial cell proliferation originating from the parent artery, as previously demonstrated. ${ }^{6}$ We also identified another molecule of interest, HHIP, which is abundantly expressed in vascular endothelial cells and involved in angiogenesis. ${ }^{68}$ We observed in our study that the expression of HHIP is down-regulated in coiled aneurysms. HHIP down-regulation is involved in the promotion of angiogenesis and could be involved in the neovascularization of the wound during the healing of coiled aneurysms. ${ }^{5,69}$

\section{Limitations}

Our study has several limitations. We used the rabbit elastase model and acknowledge that animal models are imperfect predictors of the human response. Indeed, the created aneurysms are in the mediastinum rather than the subarachnoid space and thus subject to different perianeurysmal modulations compared with berry aneurysms. Another limitation in using a model is the high degree of homogeneity among the different aneurysms, which is not the same in unselected human IAs. However, this model has been evaluated with RNA-seq and has expression patterns similar to those in human intracranial aneurysms. ${ }^{16}$ However, this aneurysm model is not one of spontaneous rupture, and some biologic pathways may differ when considering rupture-prone aneurysms. To explore these mechanisms, analyzing gene expressions in new models for active aneurysms with inflamed aneurysm walls or bioactive thrombus would be interesting. ${ }^{70,71}$ Also, time intervals between the creation of an aneurysm and the time of euthanizing the animals were different between untreated and treated aneurysms, which could introduce a difference in the healing process. Given the differences between the human and the rabbit genomes, the observed findings may not be directly applicable to the clinical 
system. As with most gene-expression studies, we recognize that any results obtained are exploratory in nature and need to be explored further; to that end, we did validate several results with reverse transcription polymerase chain reaction and will continue to explore these results further in other models.

Likewise, because of normal variations, there very likely are genes for which our threshold levels were not achieved, which may have an effect in humans. Just because a gene is not significantly up- or down-regulated does not necessarily imply that it is not relevant. Similarly, a gene found up- or down-regulated is not necessarily related to the specific question. The aim of this study was to give a general overview of gene modifications after coiling or flow-diverter treatment, not to describe all the gene variations following coil embolization or flow-diverter therapy or to identify and focus on a specific pathways or molecules. This study identifies some new parameters to explore that could be potential key factors in improving endovascular devices. This will require further validation with specific experiments to precisely describe the role of each molecule of interest.

\section{CONCLUSIONS}

RNA-sequencing analysis of rabbit aneurysms showed that despite different approaches, the response to the device used for the endovascular treatment of IAs does not vary substantially and that the mechanisms leading to aneurysm occlusion are somewhat similar, regardless of the device used. However, it revealed differential regulation of some key pathways, including inflammation and cellular migration that could explain the different biologic mechanisms implicated in aneurysm healing after either coiling or flow-diverter treatments and could be key molecules to explore to explain related complications. This study confirms wound healing being preponderant after coiling compared with flowdiverter-treated aneurysms. In addition, this study identified in the flow-diverter-treated IAs an overexpreesion of keratin 8 and basigin, implicated in the inflammatory response and in the plasminogen system.

Disclosures: Juan Cebral—RELATED: Grant: National Institutes of Health;* Comments: research grant; UNRELATED: Grants/Grants Pending: National Institutes of Health, Philips Healthcare, Comments: research grants. David F. Kallmes—RELATED: Grant: Covidien/Medtronic, ${ }^{*}$ Comments: provided devices at no cost; UNRELATED: Board Membership: GE Healthcare (Cost-Effectiveness Board)*; Consultancy: Medtronic,* Comments: planning and implementing clinical trials; Grants/Grants Pending: MicroVention, ${ }^{*}$ Sequent Medical, ${ }^{*}$ SurModics, ${ }^{*}$ Codman Neurovascular, ${ }^{*}$ ev3/Covidien/Medtronic, ${ }^{*}$ NeuroSigma, ${ }^{*}$ Comments: preclinical and clinical research; Travel/Accommodations/Meeting Expenses Unrelated to Activities Listed: Medtronic, ${ }^{\star}$ Comments: presentation at FDA panel meeting. Ramanathan KadirvelRELATED: Grant: National Institutes of Health (grant number NS076491).* *Money paid to the institution.

\section{REFERENCES}

1. Brinjikji W, Murad MH, Lanzino G, et al. Endovascular treatment of intracranial aneurysms with flow diverters: a meta-analysis. Stroke 2013;44:442-47 CrossRef Medline

2. Cebral JR, Mut F, Raschi M, et al. Aneurysm rupture following treatment with flow-diverting stents: computational hemodynamics analysis of treatment. AJNR Am J Neuroradiol 2011;32:27-33 CrossRef Medline

3. Kulcsár Z, Houdart E, Bonafé A, et al. Intra-aneurysmal thrombosis as a possible cause of delayed aneurysm rupture after flow-diversion treatment. AJNR Am J Neuroradiol 2011;32:20-25 CrossRef Medline
4. Kulcsár Z, Szikora I. The ESMINT Retrospective Analysis of Delayed Aneurysm Ruptures after flow diversion (RADAR) study. The eJournal of the European Society of Minimally Invasive Neurological Therapy 2012. http://www.ejmint.org/original-article/1244000088. Accessed December 15, 2015

5. Brinjikji W, Kallmes DF, Kadirvel R. Mechanisms of healing in coiled intracranial aneurysms: a review of the literature. AJNR AmJ Neuroradiol 2015;36:1216-22 CrossRef Medline

6. Kadirvel R, Ding YH, Dai D, et al. Cellular mechanisms of aneurysm occlusion after treatment with a flow diverter. Radiology 2014;270: 394-99 CrossRef Medline

7. Rouchaud A, Journé C, Louedec L, et al. Autologous mesenchymal stem cell endografting in experimental cerebrovascular aneurysms. Neuroradiology 2013;55:741-49 CrossRef Medline

8. Kallmes DF, Helm GA, Hudson SB, et al. Histologic evaluation of platinum coil embolization in an aneurysm model in rabbits. Radiology 1999;213:217-22 CrossRef Medline

9. Crobeddu E, Lanzino G, Kallmes DF, et al. Review of 2 decades of aneurysm-recurrence literature, part 1: reducing recurrence after endovascular coiling. AJNR Am J Neuroradiol 2013;34:266-70 CrossRef Medline

10. Raymond J, Guilbert F, Weill A, et al. Long-term angiographic recurrences after selective endovascular treatment of aneurysms with detachable coils. Stroke 2003;34:1398-403 CrossRef Medline

11. Li ZF, Fang XG, Yang PF, et al. Endothelial progenitor cells contribute to neointima formation in rabbit elastase-induced aneurysm after flow diverter treatment. CNS Neurosci Ther 2013;19:352-57 CrossRef Medline

12. Kadirvel R, Ding YH, Dai D, et al. Differential gene expression in well-healed and poorly healed experimental aneurysms after coil treatment. Radiology 2010;257:418-26 CrossRef Medline

13. Mangrum WI, Farassati F, Kadirvel R, et al. mRNA expression in rabbit experimental aneurysms: a study using gene chip microarrays. AJNR Am J Neuroradiol 2007;28:864-69 Medline

14. Kadirvel R, Ding YH, Dai D, et al. Gene expression profiling of experimental saccular aneurysms using deoxyribonucleic acid microarrays. AJNR Am J Neuroradiol 2008;29:1566-69 CrossRef Medline

15. Puffer C, Dai D, Ding YH, et al. Gene expression comparison of flow diversion and coiling in an experimental aneurysm model. J Neurointerv Surg 2015;7:926-30 CrossRef Medline

16. Holcomb M, Ding YH, Dai D, et al. RNA-sequencing analysis of messenger RNA/microRNA in a rabbit aneurysm model identifies pathways and genes of interest. AJNR Am J Neuroradiol 2015;36: 1710-15 CrossRef Medline

17. Nakaoka H, Tajima A, Yoneyama T, et al. Gene expression profiling reveals distinct molecular signatures associated with the rupture of intracranial aneurysm. Stroke 2014;45:2239-45 CrossRef Medline

18. Roder C, Kasuya H, Harati A, et al. Meta-analysis of microarray gene expression studies on intracranial aneurysms. Neuroscience 2012; 201:105-13 CrossRef Medline

19. Altes TA, Cloft HJ, Short JG, et al. 1999 ARRS Executive Council Award: creation of saccular aneurysms in the rabbit: a model suitable for testing endovascular devices-American Roentgen Ray Society. AJR Am J Roentgenol 2000;174:349-54 CrossRef Medline

20. Kallmes DF, Ding YH, Dai D, et al. A new endoluminal, flow-disrupting device for treatment of saccular aneurysms. Stroke 2007;38: 2346-52 CrossRef Medline

21. Kalari KR, Nair AA, Bhavsar JD, et al. MAP-RSeq: Mayo Analysis Pipeline for RNA sequencing. BMC Bioinformatics 2014;15:224 CrossRef Medline

22. Wang L, Wang S, Li W. RSeQC: quality control of RNA-seq experiments. Bioinformatics 2012;28:2184-85 CrossRef Medline

23. Trapnell C, Pachter L, Salzberg SL. TopHat: discovering splice junctions with RNA-Seq. Bioinformatics 2009;25:1105-11 CrossRef Medline

24. Langmead B, Trapnell C, Pop M, et al. Ultrafast and memory-effi- 
cient alignment of short DNA sequences to the human genome. Genome Biol 2009;10:R25 CrossRef Medline

25. Anders S, Pyl PT, Huber W. HTSeq-a Python framework to work with high-throughput sequencing data. Bioinformatics 2015;31: 166-69 CrossRef Medline

26. Khoo AA, Ogrizek-Tomas M, Bulovic A, et al. ExoLocator-an online view into genetic makeup of vertebrate proteins. Nucleic Acids Res 2014;42:D879-81 CrossRef Medline

27. Krämer A, Green J, Pollard J Jr, et al. Causal analysis approaches in Ingenuity Pathway Analysis. Bioinformatics 2014;30:523-30 CrossRef Medline

28. Reiner A, Yekutieli D, Benjamini Y. Identifying differentially expressed genes using false discovery rate controlling procedures. Bioinformatics 2003;19:368-75 CrossRef Medline

29. Obermajer N, Doljak B, Kos J. Cytokeratin 8 ectoplasmic domain binds urokinase-type plasminogen activator to breast tumor cells and modulates their adhesion, growth and invasiveness. Mol Cancer 2009;8:88 CrossRef Medline

30. Didiasova M, Wujak L, Wygrecka M, et al. From plasminogen to plasmin: role of plasminogen receptors in human cancer. Int $\mathrm{J} \mathrm{Mol}$ Sci 2014;15:21229-52 CrossRef Medline

31. Syrovets T, Lunov O, Simmet T. Plasmin as a proinflammatory cell activator. J Leukoc Biol 2012;92:509-19 CrossRef Medline

32. Lijnen HR. Plasmin and matrix metalloproteinases in vascular remodeling. Thromb Haemost 2001;86:324-33 Medline

33. Carmeliet P, Moons L, Lijnen R, et al. Urokinase-generated plasmin activates matrix metalloproteinases during aneurysm formation. Nat Genet 1997;17:439-44 CrossRef Medline

34. Leeper NJ, Tedesco MM, Kojima Y, et al. Apelin prevents aortic aneurysm formation by inhibiting macrophage inflammation. $A m J$ Physiol Heart Circ Physiol 2009;296:H1329-35 CrossRef Medline

35. Zhou Y, Wang Y, Qiao S. Apelin: a potential marker of coronary artery stenosis and atherosclerotic plaque stability in ACS patients. Int Heart J 2014;55:204-12 CrossRef Medline

36. Masri B, Morin N, Cornu M, et al. Apelin (65-77) activates p70 S6 kinase and is mitogenic for umbilical endothelial cells. FASEB J 2004;18:1909-11 Medline

37. Du X, Kang JP, Wu JH, et al. Elevated high sensitive C-reactive protein and apelin levels after percutaneous coronary intervention and drug-eluting stent implantation. J Zhejiang Univ Sci B 2010;11: 548-52 CrossRef Medline

38. Tulamo R, Frösen J, Hernesniemi J, et al. Inflammatory changes in the aneurysm wall: a review. J Neurointerv Surg 2010;2:120-30 CrossRef Medline

39. Frösen J. Smooth muscle cells and the formation, degeneration, and rupture of saccular intracranial aneurysm wall: a review of current pathophysiological knowledge. Transl Stroke Res 2014;5:347-56 CrossRef Medline

40. Aoki T, Kataoka H, Morimoto M, et al. Macrophage-derived matrix metalloproteinase- 2 and -9 promote the progression of cerebral aneurysms in rats. Stroke 2007;38:162-69 CrossRef Medline

41. Kadirvel R, Dai D, Ding YH, et al. Endovascular treatment of aneurysms: healing mechanisms in a swine model are associated with increased expression of matrix metalloproteinases, vascular cell adhesion molecule-1, and vascular endothelial growth factor, and decreased expression of tissue inhibitors of matrix metalloproteinases. AJNR Am J Neuroradiol 2007;28:849-56 Medline

42. Courtois A, Nusgens BV, Hustinx R, et al. 18F-FDG uptake assessed by PET/CT in abdominal aortic aneurysms is associated with cellular and molecular alterations prefacing wall deterioration and rupture. J Nucl Med 2013;54:1740 - 47 CrossRef Medline

43. Morris DR, Biros E, Cronin O, et al. The association of genetic variants of matrix metalloproteinases with abdominal aortic aneurysm: a systematic review and meta-analysis. Heart 2014;100: 295-302 CrossRef Medline

44. Saracini C, Bolli P, Sticchi E, et al. Polymorphisms of genes involved in extracellular matrix remodeling and abdominal aortic aneurysm. J Vasc Surg 2012;55:171-79 e2 CrossRef Medline
45. Wilson WR, Anderton M, Choke EC, et al. Elevated plasma MMP1 and MMP9 are associated with abdominal aortic aneurysm rupture. Eur J Vasc Endovasc Surg 2008;35:580 - 84 CrossRef Medline

46. Chase AJ, Newby AC. Regulation of matrix metalloproteinase (matrixin) genes in blood vessels: a multi-step recruitment model for pathological remodelling. J Vasc Res 2003;40:329-43 CrossRef Medline

47. Xiong W, Knispel R, MacTaggart J, et al. Membrane-type 1 matrix metalloproteinase regulates macrophage-dependent elastolytic activity and aneurysm formation in vivo. J Boil Chem 2009;284: 1765-71 CrossRef Medline

48. Dai X, Shen J, Annam NP, et al. SMAD3 deficiency promotes vessel wall remodeling, collagen fiber reorganization and leukocyte infiltration in an inflammatory abdominal aortic aneurysm mouse model. Sci Rep 2015;5:10180 CrossRef Medline

49. Didangelos A, Yin X, Mandal K, et al. Extracellular matrix composition and remodeling in human abdominal aortic aneurysms: a proteomics approach. Mol Cell Proteomics 2011;10:M111.008128 CrossRef Medline

50. Zhang B, Dhillon S, Geary I, et al. Polymorphisms in matrix metalloproteinase-1, $-3,-9$, and -12 genes in relation to subarachnoid hemorrhage. Stroke 2001;32:2198-202 CrossRef Medline

51. Curci JA, Liao S, Huffman MD, et al. Expression and localization of macrophage elastase (matrix metalloproteinase-12) in abdominal aortic aneurysms. J Clin Invest 1998;102:1900-10 CrossRef Medline

52. Tromp G, Gatalica Z, Skunca M, et al. Elevated expression of matrix metalloproteinase-13 in abdominal aortic aneurysms. Ann Vasc Surg 2004;18:414-20 CrossRef Medline

53. Bouzeghrane F, Darsaut T, Salazkin I, et al. Matrix metalloproteinase- 9 may play a role in recanalization and recurrence after therapeutic embolization of aneurysms or arteries. J Vasc Interv Radiol 2007;18:1271-79 CrossRef Medline

54. Chen XF, Wang JA, Hou J, et al. Extracellular matrix metalloproteinase inducer (EMMPRIN) is present in smooth muscle cells of human aneurysmal aorta and is induced by angiotensin II in vitro. Clin Sci (Lond) 2009;116:819-26 CrossRef Medline

55. Lizarbe TR, Tarín C, Gómez M, et al. Nitric oxide induces the progression of abdominal aortic aneurysms through the matrix metalloproteinase inducer EMMPRIN. Am J Pathol 2009;175:1421-30 CrossRef Medline

56. Kazi M, Zhu C, Roy J, et al. Difference in matrix-degrading protease expression and activity between thrombus-free and thrombus-covered wall of abdominal aortic aneurysm. Arterioscler Thromb Vasc Boil 2005;25:1341-46 CrossRef Medline

57. Fontaine V, Jacob MP, Houard X, et al. Involvement of the mural thrombus as a site of protease release and activation in human aortic aneurysms. Am J Pathol 2002;161:1701-10 CrossRef Medline

58. Li Q, Laumonnier Y, Syrovets T, et al. Plasmin triggers cytokine induction in human monocyte-derived macrophages. Arterioscler Thromb Vasc Biol 2007;27:1383-89 CrossRef Medline

59. Burysek L, Syrovets T, Simmet T. The serine protease plasmin triggers expression of MCP-1 and CD40 in human primary monocytes via activation of p38 MAPK and janus kinase (JAK)/ STAT signaling pathways. J Biol Chem 2002;277:33509-17 CrossRef Medline

60. Reilly JM. Plasminogen activators in abdominal aortic aneurysmal disease. Ann N Y Acad Sci 1996;800:151-56 CrossRef Medline

61. Coutard M, Touat $Z$, Houard X, et al. Thrombus versus wall biological activities in experimental aortic aneurysms. J Vasc Res 2010;47: 355-66 CrossRef Medline

62. Killer M, Plenk H, Minnich B, et al. Histological demonstration of healing in experimental aneurysms. Minim Invasive Neurosurg 2009; 52:170-75 CrossRef Medline

63. Daley JM, Brancato SK, Thomay AA, et al. The phenotype of murine wound macrophages. J Leukoc Biol 2010;87:59-67 CrossRef Medline

64. van den Berg LM, Ziilstra-Willems EM, Richters CD, et al. Dectin-1 activation induces proliferation and migration of human keratino- 
cytes enhancing wound re-epithelialization. Cell Immunol 2014; 289:49-54 CrossRef Medline

65. Roy S, Dickerson R, Khanna S, et al. Particulate $\boldsymbol{\beta}$-glucan induces TNF- $\alpha$ production in wound macrophages via a redox-sensitive NF- $\boldsymbol{\beta} \boldsymbol{\beta}$-dependent pathway. Wound Repair Regen 2011;19:411-19 CrossRef Medline

66. Beer HD, Bittner M, Niklaus G, et al. The fibroblast growth factor binding protein is a novel interaction partner of FGF-7, FGF-10 and FGF-22 and regulates FGF activity: implications for epithelial repair. Oncogene 2005;24:5269-77 CrossRef Medline

67. Tassi E, McDonnell K, Gibby KA, et al. Impact of fibroblast growth factor-binding protein-1 expression on angiogenesis and wound healing. Am J Pathol 2011;179:2220-32 CrossRef Medline
68. Olsen CL, Hsu PP, Glienke J, et al. Hedgehog-interacting protein is highly expressed in endothelial cells but down-regulated during angiogenesis and in several human tumors. BMC Cancer 2004;4:43 CrossRef Medline

69. Wong VW, Crawford JD. Vasculogenic cytokines in wound healing. Biomed Res Int 2013;2013:190486 CrossRef Medline

70. Gounis MJ, van der Bom IM, Wakhloo AK, et al. MR imaging of myeloperoxidase activity in a model of the inflamed aneurysm wall. AJNR Am J Neuroradiol 2015;36:146-52 CrossRef Medline

71. Delbosc S, Alsac JM, Journe C, et al. Porphyromonas gingivalis participates in pathogenesis of human abdominal aortic aneurysm by neutrophil activation: proof of concept in rats. PLoS One 2011;6: e18679 CrossRef Medline 